\title{
Transmission of Ostreid herpesvirus-1 in Crassostrea gigas by cohabitation: effects of food and number of infected donor oysters
}

\author{
Olivia Evans, Paul Hick, Navneet Dhand, Richard J. Whittington*
}

Faculty of Veterinary Science, The University of Sydney, 425 Werombi Road, Camden, NSW 2570, Australia

\begin{abstract}
Ostreid herpesvirus-1 (OsHV-1) causes severe mortalities in commercially produced Crassostrea gigas, with oysters $<1 \mathrm{yr}$ of age being the most susceptible. It presents a significant threat to C. gigas aquaculture worldwide. Understanding the mechanisms behind the complex interactions of the pathogen, host and environment and the mode of transmission of the virus has been difficult. The aims of this study were to (1) investigate the role that food plays in OsHV-1 transmission and mortality and (2) assess the dose-response effect represented by the number of OsHV-1-infected donor oysters cohabitated with healthy naïve oysters. Both addition of food and the number of donor oysters were important risk factors for OsHV-1 transmission and clinical disease in an aquarium model. Cumulative mortality was higher and incubation period (median time to death) was lower in fed oysters compared with non-fed oysters. Depending on the number of infected donors, fed oysters had a hazard of death 3.55 to 13.70 times that of non-fed oysters in the first $7 \mathrm{~d}$ post-exposure. Mortality rates were doubled when 6 donor oysters were included per tank compared with 2 donors in the first experiment. The severity of disease was lower in a second experiment conducted on a different batch of oysters. However, there was a consistent trend for increased hazard of death associated with food. OsHV-1 DNA was detected in aquarium water in both experiments but at low levels compared with prior studies, probably due to larger water volume, biofiltration and UV treatment. Results are consistent with the OsHV-1 particle attachment hypothesis; however, the adsorption of OsHV-1 to algal food particles and the effects of their ingestion are yet to be confirmed.
\end{abstract}

KEY WORDS: Ostreid herpesvirus-1 $\cdot$ Crassostrea gigas $\cdot$ Cohabitation $\cdot$ Feeding $\cdot$ Dose

\section{INTRODUCTION}

Ostreid herpesvirus-1 (OsHV-1) is a member of the family Malacoherpesviridae within the order Herpesvirales (ICTV 2013) and is an important pathogen causing mass mortality events in the Pacific oyster (Crassostrea gigas) (Pepin et al. 2008, Segarra et al. 2010). A variant of OsHV-1 known as $\mu$ Var has been the predominant virus in mass mortality events since 2008 (Segarra et al. 2010, Martenot et al. 2011, Martenot 2013). OsHV-1 represents a significant threat to the C. gigas aquaculture industries in Australia (Jenkins et al. 2013, Paul-Pont et al. 2014), New

${ }^{*}$ Corresponding author: richard.whittington@sydney.edu.au
Zealand (Keeling et al. 2014), Europe (Renault \& Arzul 2001, Garcia et al. 2011, Peeler et al. 2012, Roque et al. 2012) and Asia (Shimahara et al. 2012, Hwang et al. 2013, Bai et al. 2015). All age and size classes can be affected with losses of $40-100 \%$ reported in commercially produced C. gigas in Australia (Paul-Pont et al. 2014, Whittington et al. 2015a). However, young oysters of $<1 \mathrm{yr}$ of age are the most susceptible to the disease (Arzul et al. 2002, Dégremont et al. 2010, Garcia et al. 2011, Schikorski et al. 2011b, Dégremont 2013, Paul-Pont et al. 2013b).

Summer mortalities in adult C. gigas were first identified in the USA and Japan in the early 1960s,

() The authors 2015. Open Access under Creative Commons by Attribution Licence. Use, distribution and reproduction are unrestricted. Authors and original publication must be credited. 
with herpes-like viruses noted to occur in bivalves, such as C. virginica, in 1972 (Farley et al. 1972, Mori 1979). However, investigation into the herpesvirus infecting C. gigas did not begin until the early 1990s (Nicholas et al. 1992, Renault et al. 1994). OsHV-1 related mortalities in the field occur as a result of complex interactions between the oyster, the pathogen and the environment (Paul-Pont et al. 2013a, Petton et al. 2015). Understanding the mechanisms behind these interactions and the mode of transmission of the virus has proven to be difficult. A threshold temperature of approximately $16^{\circ} \mathrm{C}$ has been shown to be important for OsHV-1 disease expression in Europe, where outbreaks occur at temperatures of $16-24^{\circ} \mathrm{C}$ (Oden et al. 2011, Pernet et al. 2012, Petton et al. 2013, Renault et al. 2014). In Australia, however, the permissive temperature range is not yet defined, although outbreaks have been observed at temperatures of 22-25 ${ }^{\circ} \mathrm{C}$ (Jenkins et al. 2013, Paul-Pont et al. 2013b). Similarly it has been suggested that farming site (Cotter et al. 2010, Paul-Pont et al. 2013a), husbandry (Pernet et al. 2012, Normand et al. 2014, Whittington et al. 2015a), oyster age, size and genotype (Dégremont et al. 2010, Dégremont 2013), starvation and oyster energy reserves (Tamayo et al. 2014, Moreau et al. 2015), and seawater nutrient levels (Pernet et al. 2014) may affect OsHV-1 disease expression. More investigation is required, however, in order to ascertain the key risk factors for OsHV-1 related mortality events.

The results of prior studies have suggested that horizontal transmission of OsHV-1 may occur through seawater (Vigneron et al. 2004, Sauvage et al. 2009, Schikorski et al. 2011a). In aquarium studies OsHV-1 was transmitted by cohabitation of infected oysters with naïve oysters in $1 \mu \mathrm{m}$ filtered seawater, and virus concentrations in tank water ranged between $10^{1}$ and $10^{3}$ DNA copies per microliter over the $168 \mathrm{~h}$ sampling period (Schikorski et al. 2011a). Studies by Evans et al. (2014) suggest that OsHV-1 may be present in seawater in a range of forms, including free virus, flocculated, or aggregated virus, virus adsorbed to particles, or various viral components including free DNA. Studies of natural transmission events strongly suggest that an aquatic mechanical vector or particle may be associated with OsHV-1 transmission (Paul-Pont et al. 2013a, Whittington et al. 2015a). The spatial clustering of exposure events was similar to that seen in planktonic aggregations and communities (Paul et al. 1993, Kingsford \& Suthers 1994, 1996, Ryan et al. 2008, Rissik et al. 2009, Benoit-Bird \& McManus 2012), and it was hypothesised that the virus could be attached to such particles (Paul-Pont et al. 2013a). Thus, OsHV-1 is a waterborne, communicable virus, and it is probable that particles, including plankton, may play a significant role in its transmission. However, the nature of the particles and whether or not they could be food particles remains unclear. Acute Viral Necrosis Virus (AVNV), now understood to be a variant of OsHV-1 (Bai et al. 2015), has been previously detected in phytoplankton samples in China by quantitative PCR (Wang et al. 2010). It has been suggested that AVNV is capable of associating with several species of marine microalgae, which when fed to Zhikong scallops (Chlamys farreri) caused significant clinical mortalities in comparison to scallops fed on non-infected microalgae (Zhang et al. 2010).

Studies by Petton et al. (2015) demonstrated the effects of infected oyster biomass and water renewal using the cohabitation model. As the biomass of infected oysters increased, so did the odds of mortality in cohabitating $C$. gigas. Furthermore, as the rate of water renewal increased, the odds of mortality decreased. The donors used in this cohabitation model were exposed to OsHV-1 in the field prior to use in the laboratory. Thus, it is likely that biota other than OsHV-1 were also introduced into the cohabitation system. Nevertheless, it is apparent that the biomass of infected oysters may be useful as a proxy for the dose of OsHV-1 in cohabitation models, and alteration of the number of OsHV-1 infected donor oysters in an aquarium system may allow for simulation of different OsHV-1 doses by means of natural exposure.

The aims of this study were to (1) assess the effects of algal food on OsHV-1 infection and clinical disease (mortality) by comparison of fed versus not fed treatments and (2) assess the role of the infected oyster biomass on OsHV-1 infection and clinical disease in an aquarium cohabitation model, where the dose of OsHV-1 was represented by the number of OsHV-1 infected donor oysters. This source of virus may be closer to a natural state compared with a virus that has been manipulated by purification from oyster tissues (Paul-Pont et al. 2015). It was hypothesised that the presence of food and increasing the number of OsHV-1 infected oysters in a tank would increase the risk of mortality.

\section{MATERIALS AND METHODS}

\section{Experiments}

Two experiments were conducted at the University of Sydney laboratories in Camden, NSW, Australia. Expt 1 was conducted over a $10 \mathrm{~d}$ period from $21 \mathrm{Sep}$ - 
tember 2013 to 1 October 2013, with the aim of assessing the effects of food presence and the number of OsHV-1 infected donor oysters on OsHV-1 infection and clinical disease. The number of donor oysters was a proxy for the dose of OsHV-1. Expt 2 was conducted over a $22 \mathrm{~d}$ period from 11 February 2015 to 4 March 2015, with the aim of assessing feeding versus not feeding and 2 discontinuous periods of OsHV-1 exposure.

\section{Oysters and experimental design}

For the first experiment, 492 healthy, triploid Crassostrea gigas, which had never been exposed to OsHV-1, were acquired from OsHV-1 free populations in the Shoalhaven River (Goodnight Oysters, Greenwell Point, NSW, Australia; juveniles 9 mo old, $5.0 \pm 3.0$ g; $\mathrm{n}=470$ ) and the Hawkesbury River estuary (Broken Bay Oysters, Mooney Mooney, NSW, Australia; adults 18 mo old, $28.0 \pm 5.0$ g; $\mathrm{n}=$ 22) in January 2013, which was prior to the onset of OsHV-1 related disease in that estuary. The batches of oysters from which the experimental animals were obtained were confirmed OsHV-1 negative by real-time quantitative PCR (qPCR) prior to use. Juveniles from the Shoalhaven River were randomly divided between 4 treatment groups and 2 control groups. The remaining juveniles $(\mathrm{n}=50)$ and adult Hawkesbury River oysters were designated for intramuscular injection of OsHV-1 and acted as OsHV-1 donor oysters. The experimental design is shown in Table 1. Briefly, 30 oysters were randomly allocated to each of 3 tanks for each treatment, with 2 control groups $(n=30)$. Oysters were either fed $\left(\mathrm{F}^{+}\right)$or not fed $\left(\mathrm{F}^{-}\right)$, and there were either a high $(\mathrm{H}$, $\mathrm{n}=10)$ or low $(\mathrm{L}, \mathrm{n}=2)$ number of donor oysters per tank in treatment tanks. Negative controls were not purposely exposed to OsHV-1.

For the second experiment, 608 healthy, triploid C. gigas oysters were acquired from OsHV-1 free populations in the Shoalhaven River (Goodnight Oysters, Greenwell Point, NSW, Australia; batches: juveniles 9 mo old, $5.5 \pm 2.1 \mathrm{~g}$ and adults 18 mo old, $32.3 \pm 7.3 \mathrm{~g}$ ) in January 2015. The batches of oysters were confirmed OsHV-1 negative by real-time qPCR prior to use. The experimental design is shown in Table 2. A dose regime was used to simulate successive exposure periods as may occur over a summer season when oysters that survive a mortality event are re-exposed. The first exposure was from Day 1 to 4, while the second was from Day 9 to 12. It was apparent as the experiment progressed that the first exposure was insufficient to induce mortality over $8 \mathrm{~d}$; thus, a higher dose was utilised for the second exposure. During the first exposure period, 2 donor oysters were cohabitated with naïve C. gigas; all donors were removed on Day 4. During the second exposure period, the survivors were cohabitated with 6 OsHV-1 donors per tank and all donors were removed on Day 12. Oysters were fed under different regimes. Briefly, the always fed (AF) group was fed from Day 1 to 22, the fed then starved (FS) group was fed from Day 1 to 4 only, the starved then fed (SF) group was fed from Day 5 to 22 only and the always starved (AS) group was not fed; negative control oysters received the same regimes but were not purposely exposed to OsHV-1. Briefly, 30 juvenile oysters were randomly allocated to each of 3 tanks for each of the feeding treatments, and to 4 separate tanks for the controls. The remaining oysters were allocated for intramuscular injection of OsHV-1 positive inoculum ( $\mathrm{n}=96)$, and therefore acted as infected donor oysters (Table 2).

Table 1. Design of Expt 1 to assess the effects of food presence and the number of OsHV-1 infected donor oysters on OsHV-1 infection and clinical disease. OsHV-1 donor oysters received intramuscular injection of OsHV-1 inoculum $1 \mathrm{~h}$ prior to cohabitation

\begin{tabular}{|c|c|c|c|c|c|c|c|}
\hline Group & $\begin{array}{l}\text { Abbrevi- } \\
\text { ations }\end{array}$ & $\begin{array}{c}\text { Recirculation } \\
\text { system }\end{array}$ & $\begin{array}{l}\text { Number } \\
\text { of tanks }\end{array}$ & $\begin{array}{l}\text { Number of } \\
\text { naïve oysters } \\
\text { per tank }\end{array}$ & $\begin{array}{c}\text { Number of } \\
\text { naïve oysters } \\
\text { per treatment }\end{array}$ & $\begin{array}{l}\text { Number } \\
\text { of donors } \\
\text { per tank }\end{array}$ & $\begin{array}{c}\text { Number of } \\
\text { donor oysters } \\
\text { per treatment }\end{array}$ \\
\hline \multicolumn{8}{|l|}{ Treatment } \\
\hline High number donors with feed & $\mathrm{HF}^{+}$ & 1 & 3 & 30 & 90 & 10 & 30 \\
\hline High number donors without feed & $\mathrm{HF}^{-}$ & 2 & 3 & 30 & 90 & 10 & 30 \\
\hline Low number donors with feed & $\mathrm{LF}^{+}$ & 3 & 3 & 30 & 90 & 2 & 6 \\
\hline Low number donors without feed & $\mathrm{LF}^{-}$ & 4 & 3 & 30 & 90 & 2 & 6 \\
\hline \multicolumn{8}{|l|}{ Controls } \\
\hline Negative control with feed & $\mathrm{NF}^{+}$ & No recirculation & 1 & 30 & 30 & 0 & 0 \\
\hline Negative control without feed & $\mathrm{NF}^{-}$ & No recirculation & 1 & 30 & 30 & 0 & 0 \\
\hline
\end{tabular}


Table 2. Design of Expt 2 to assess feeding versus not feeding on 2 discontinuous periods of OsHV-1 exposure. Oysters were exposed to OsHV-1 infected donor oysters on Days 1-4 (Exposure Period 1: $\mathrm{n}=6$ donors per treatment) and Days 9-12 (Exposure Period 2: $\mathrm{n}=$ 18 donors per treatment). Donor oysters received intramuscular injection of OsHV-1 inoculum or control inoculum $1 \mathrm{~h}$ prior to the respective exposure period

\begin{tabular}{|c|c|c|c|c|c|c|c|c|c|c|}
\hline \multirow[t]{2}{*}{ Group } & \multirow{2}{*}{$\begin{array}{c}\text { Feeding } \\
\text { days }\end{array}$} & \multirow{2}{*}{$\begin{array}{l}\text { Abbrevi- } \\
\text { ations }\end{array}$} & \multirow{2}{*}{$\begin{array}{l}\text { Recirculation } \\
\text { system }\end{array}$} & \multirow{2}{*}{$\begin{array}{c}\text { Number } \\
\text { of } \\
\text { tanks }\end{array}$} & \multirow{2}{*}{$\begin{array}{c}\text { Oysters } \\
\text { per } \\
\text { tank }\end{array}$} & \multirow{2}{*}{$\begin{array}{l}\text { Oysters } \\
\text { per } \\
\text { treatment }\end{array}$} & \multicolumn{2}{|c|}{ Exposure Period 1} & \multicolumn{2}{|c|}{ Exposure Period 2} \\
\hline & & & & & & & $\begin{array}{c}\text { Donor } \\
\text { oysters } \\
\text { per tank }\end{array}$ & $\begin{array}{l}\text { Donor } \\
\text { oysters per } \\
\text { treatment }\end{array}$ & $\begin{array}{c}\text { Donor } \\
\text { oysters } \\
\text { per tank }\end{array}$ & $\begin{array}{c}\text { Donor } \\
\text { oysters per } \\
\text { treatment }\end{array}$ \\
\hline \multicolumn{11}{|l|}{ Treatment } \\
\hline 1 (always fed) & $1-22$ & $\mathrm{AF}$ & 1 & 3 & 30 & 90 & 2 & 6 & 6 & 18 \\
\hline 2 (fed then starved) & $1-4$ & FS & 2 & 3 & 30 & 90 & 2 & 6 & 6 & 18 \\
\hline 3 (starved then fed) & $5-22$ & SF & 3 & 3 & 30 & 90 & 2 & 6 & 6 & 18 \\
\hline 4 (always starved) & None & AS & 4 & 3 & 30 & 90 & 2 & 6 & 6 & 18 \\
\hline \multicolumn{11}{|l|}{ Controls } \\
\hline Control AF & $1-22$ & CAF $\mathrm{I}$ & No recirculation & 1 & 30 & 30 & 2 & 2 & 6 & 6 \\
\hline Control FS & $1-4$ & CFS I & No recirculation & 1 & 30 & 30 & 2 & 2 & 6 & 6 \\
\hline Control SF & $5-22$ & CSF $\quad 1$ & No recirculation & 1 & 30 & 30 & 2 & 2 & 6 & 6 \\
\hline Control AS & None & CAS I & No recirculation & 1 & 30 & 30 & 2 & 2 & 6 & 6 \\
\hline
\end{tabular}

Donors injected with OsHV-1 negative control tissue homogenate $(\mathrm{n}=32)$ were used for the control groups (Table 2).

\section{Random sampling and mortality data}

Oyster mortality was assessed daily by visual inspection and by manually counting the numbers of dead oysters.

For Expt 1 opportunistic, non-selective sampling of 6 live oysters per treatment tank and 2 live oysters per negative control tank was performed once daily prior to morning feeding. Dead oysters, including both the cohabitants and the donors, were sampled on the day they were observed. All oysters that survived to Day 10 were sampled. All oysters removed by sampling or as a result of mortality were frozen at $-80^{\circ} \mathrm{C}$ until required for qPCR analysis.

For Expt 2 opportunistic, non-selective sampling of 8 live oysters per tank in the treatments and controls was performed on Days 4 and 17 in order to determine the prevalence of infection. Mortalities were sampled on the day they were observed. Donor oysters were present in each treatment from Day 1 to 4 (Exposure Period 1) and Day 9 to 12 (Exposure Period 2) (Table 2). Donors were monitored daily for mortality but were not removed from the system until Days 4 and 12, for Exposure Periods 1 and 2, respectively. All oysters remaining at Day 22 were sampled for endpoint prevalence calculation. All oysters removed by sampling or as a result of mortality were frozen at $-80^{\circ} \mathrm{C}$ until required for qPCR analysis.
The cumulative mortality of cohabitant $C$. gigas in each treatment group was calculated according to the method described by Whittington et al. (2015a) taking into account the number of live oysters sampled at each time point.

\section{Husbandry of oysters}

Experiments were undertaken in a physical containment level 2 (PC2) aquatic animal facility. For both experiments, 4 separate recirculation systems were utilised, each containing 3 tanks (15 1) per treatment across which the oysters were evenly divided (FRESH ${ }^{\circledR}$ by Design). Each recirculation system had a sump (250 1) that was connected to biofiltration, a chiller unit $\left(22^{\circ} \mathrm{C}, \mathrm{HC}-300 \mathrm{~A}\right.$, Hailea Aquarium chiller) and an ultra-violet light (SMART UV Sterilizer; $25 \mathrm{~W}-30 \mathrm{LMP} / 1800 \mathrm{LPH}$ at $30 \mathrm{~mJ}$ $\mathrm{cm}^{-2}$ [90\% UVT] $40 \mathrm{~mm}$ connections; Emperor Aquatics). Oysters in each tank were evenly distributed (not touching: $2 \mathrm{~cm}$ apart) over a raised, perforated, plastic insert $10 \mathrm{~cm}$ above the tank floor. Negative controls (oysters never exposed to OsHV-1) were maintained in separate 151 tanks with no inserts, recirculation, biofiltration, or UV systems. All treatment and control tanks were supplied with artificial seawater (30-31 ppt salinity; Red Sea) and aeration, and were maintained at a temperature of $22^{\circ} \mathrm{C}$ and $\mathrm{pH} 8.2$ (range: $8.2-8.8$ ), and ammonia, nitrite and nitrate levels $<0.25 \mathrm{ppm}$. All water quality parameters were monitored daily throughout both trials, and adjustments were per- 
formed as required by water exchange. Oysters for both trials were given a $2 \mathrm{~d}$ acclimation period at $22^{\circ} \mathrm{C}$ prior to the beginning of the experimental period during which they were not fed. The acclimation temperature was similar to estuarine temperatures at the locations where the oysters were previously located.

\section{Feeding}

Oysters were fed according to the recommendations of the FAO (2004) and Reed Mariculture. In Expt 1 , oysters were fed with Instant Algae ${ }^{\circledR}$ Shellfish Diet 1800 (Reed Mariculture), a concentrate of marine microalgae $(5-20 \mu \mathrm{m})$ containing a mix of Isochrysis, Pavlova, Thalassiosira weissflogii and Tetraselmis. Feeding rate per tank was calculated daily using the feed calculator available at www.reedmariculture. com/support_feeding_shellfish.php which determines feeding rate according to the total wet weight of the meat of the oysters in each tank. The $\mathrm{HF}^{+}, \mathrm{LF}^{+}$and $\mathrm{NF}^{+}$ oysters were fed twice daily (morning and afternoon) for the duration of the experiment. The $\mathrm{HF}^{-}, \mathrm{LF}^{-}$and $\mathrm{NF}^{-}$oysters were not fed during the experiment.

In Expt 2, oysters were fed twice daily (morning and afternoon) with Instant Algae ${ }^{\circledR}$ Shellfish Diet 1800. For this experiment, $20 \mathrm{ml}$ of feed was added to the appropriate tanks daily.

During the feeding period each tank (both fed and not fed) was isolated from the recirculation, biofiltration and UV treatment for $2 \mathrm{~h}$ so that the tanks were undisturbed. However, water in the sumps was recirculated via the biofiltration and UV units. Negative control tanks were not connected to recirculation, so each tank received a total water exchange after each feeding session.

\section{Preparation of OsHV-1 inoculum}

Oysters that were used for the preparation of OsHV-1 infected inoculum were collected during an OsHV-1 related mortality event in Woolooware Bay, Georges River estuary, NSW, Australia, in November 2012 and were stored at $-80^{\circ} \mathrm{C}$. Oysters were confirmed to be positive for OsHV-1 DNA using the real time qPCR method of Martenot et al. (2010) as described by Paul-Pont et al. (2013b) .

To prepare the inoculum 5 oysters (in shell) were removed from $-80^{\circ} \mathrm{C}$ and thawed at $4^{\circ} \mathrm{C}$ overnight. To confirm infection with OsHV-1, a piece of gill and mantle $(0.08-0.12 \mathrm{~g})$ was dissected from each oyster using sterile, disposable dissecting instruments and placed into a $1.5 \mathrm{ml}$ tube containing $1 \mathrm{ml}$ of distilled water (Ultrapure ${ }^{\mathrm{TM}}$ ) and silica beads (Daintree Scientific), and frozen at $-80^{\circ} \mathrm{C}$ until processing for qPCR. All remaining gill and mantle were excised, pooled (n $=5$ ), weighed and diluted in 10 vol with sterile $0.22 \mu \mathrm{m}$ filtered synthetic seawater (FSSW; RedSea salt, 30 ppt) in a stomaching bag (Interscience). Tissues were disaggregated in a MiniMix ${ }^{\circledR}$ machine (Crown Scientific) at maximum speed for $1 \mathrm{~min}$. The tissue homogenate was pipetted into a sterile $50 \mathrm{ml}$ polypropylene tube (Falcon) and centrifuged at $1000 \times g$ for $5 \mathrm{~min}$ at $4^{\circ} \mathrm{C}$. Some of the clarified homogenate was cryopreserved in $10 \% \mathrm{v} / \mathrm{v}$ glycerol and $10 \% \mathrm{v} / \mathrm{w}$ foetal bovine serum by controlled freezing in insulated boxes at $-80^{\circ} \mathrm{C}$ for use in Expt 2 (University of Sydney Batch V172). The remainder was then transferred to a new sterile $50 \mathrm{ml}$ tube and diluted by 3 vol with FSSW, then filtered sequentially through an 8.00, 3.00, 0.45 and two $0.22 \mu \mathrm{m}$ filters (MILLEX ${ }^{\circledR}$-GP, Millipore). The filtered homogenate was diluted by a further 3 vol with FSSW to a final dilution of the original tissue of $0.13 \% \mathrm{w} / \mathrm{v}$ and was stored briefly at $4^{\circ} \mathrm{C}$. This inoculum contained approximately $1 \times 10^{5} \mathrm{DNA}$ copies $\mathrm{\mu l}^{-1}$ and was used to inject oysters in Expt 1 on the day it was prepared, 20 September 2013.

For Expt 2, V172 was used together with a negative control batch of inoculum that was prepared using apparently healthy C. gigas acquired from diseasefree populations in the Shoalhaven River (Goodnight Oysters, Greenwell Point, NSW, Australia) in December 2013. The negative control inoculum was prepared and cryopreserved in December 2013 as University of Sydney Batch V170. The inoculums were thawed at $4^{\circ} \mathrm{C}$ prior to $1: 100$ dilution in distilled water (Ultrapure $^{\mathrm{TM}}$ ). The OsHV-1 positive inoculum contained approximately $1 \times 10^{4}$ viral copies $\mathrm{\mu l}^{-1}$.

For both experiments, $100 \mu \mathrm{l}$ of the diluted inoculums was drawn up into separate $1 \mathrm{ml}$ tuberculin syringes just prior to injection and syringes were kept on wet ice until injection, with OsHV-1 negative and positive inoculums kept separate.

\section{Inoculation of donor oysters}

Oysters to be injected were placed out of water for $24 \mathrm{~h}$ at $22^{\circ} \mathrm{C}$ and then relaxed in a solution of $\mathrm{MgCl}_{2}$ $\left(50 \mathrm{~g} \mathrm{l}^{-1}\right)$ at $22^{\circ} \mathrm{C}$ for 4 to $6 \mathrm{~h}$. Once relaxed, the oysters were rinsed briefly in artificial seawater and injected in the adductor muscle with $100 \mu \mathrm{l}$ of inoculum. Control donor oysters used in Expt 2 were injected prior to infected donor oysters, and kept separate from them. 
Injected oysters were kept out of water for $10 \mathrm{~min}$ post-injection and then randomly assigned to 1 of the 4 treatment groups or control tanks (Tables 1 \& 2).

\section{Water sampling}

For Expt 1, water samples were collected 4 times a day using clean transfer pipettes (Copan) - Time 1 [T1]: at the start of each day prior to feeding (the water had been exposed to biofiltration and UV by recirculation overnight); Time 2 [T2]: at the end of the morning feeding session (there had been no recirculation, UV, or biofiltration for $2 \mathrm{~h}$ ); Time 3 [T3]: at the end of the afternoon feeding session (there had been no recirculation, $\mathrm{UV}$, or biofiltration for $2 \mathrm{~h}$ ); Time 4 [T4]: at the end of each day (there had been recirculation, UV and biofiltration for $2 \mathrm{~h}$ since T3). A sample of $1 \mathrm{ml}$ was collected from each treatment tank and system sump and from each control tank and was placed into a $1.5 \mathrm{ml}$ screw cap tube for storage at $-80^{\circ} \mathrm{C}$ until DNA extraction. Samples were collected for the duration of the experiment.

For Expt 2, water samples were collected twice daily as above at T1 and T3. A sample of $50 \mathrm{ml}$ was collected from each treatment tank, treatment sump and control tank, and a $1 \mathrm{ml}$ aliquot was placed into a $1.5 \mathrm{ml}$ tube containing $0.4 \mathrm{~g}$ of silica-zirconia beads (Daintree Scientific) for storage at $-80^{\circ} \mathrm{C}$ until tissue homogenisation and DNA extraction. Samples were collected from Day 1 to 14 of the experiment.

\section{Dissection and tissue homogenisation}

Live oysters, dead oysters and donor oysters were processed separately from one another. Oysters were thawed overnight at $4^{\circ} \mathrm{C}$. A piece of gill and mantle (0.08-0.12 g) was dissected from each individual oyster using sterile, disposable dissecting instruments and placed into a $1.5 \mathrm{ml}$ tube containing $1 \mathrm{ml}$ of distilled water (Ultrapure ${ }^{\mathrm{TM}}$ ) and $0.4 \mathrm{~g}$ of silica-zirconia beads (Daintree Scientific). Tubes were frozen at $-80^{\circ} \mathrm{C}$ until tissue homogenisation.

All $1.5 \mathrm{ml}$ tubes containing tissue samples and water samples were subjected to the same homogenisation procedure to separate the virus from cells and particles in the sample.

Tubes were thawed for 20 min and placed into a bead-beating machine (Fastprep ${ }^{\circledR}-24$ System, MP Biomedical) for $15 \mathrm{~s}$ at a speed of $6.5 \mathrm{~m} \mathrm{~s}^{-1}$ (Expt 1) or a TissueLyser II machine (Qiagen ${ }^{\circledR}$ ) for 2 min at frequency 30 , then the insert containing the samples was rotated $180^{\circ}$ and the homogenisation was repeated (Expt 2). All samples were clarified by centrifugation at $900 \times g$ for $10 \mathrm{~min}$ in a microcentrifuge (Heraeus ${ }^{\circledR}$ Biofuge ${ }^{\circledR}$ Pico, Thermo Electron Corporation), and supernatants were stored at $-80^{\circ} \mathrm{C}$ until DNA extraction.

\section{Nucleic acid purification}

Nucleic acids were purified from each clarified tissue homogenate and water sample using a 5× MagMAX $^{\mathrm{TM}}$-96 Viral RNA Isolation Kit (Ambion ${ }^{\circledR}$, Life Technologies $^{\mathrm{TM}}$ ) and a MagMAX ${ }^{\mathrm{TM}}$ Express 96 magnetic particle processor (Applied Biosystems ${ }^{\mathrm{TM}}$, Life Technologies ${ }^{\mathrm{TM}}$ ) according to the manufacturer's instructions for a $50 \mu \mathrm{l}$ sample volume protocol using the AM1836 deep-well standard program (Ambion ${ }^{\circledR}$, Life Technologies ${ }^{\mathrm{TM}}$ ). A $50 \mu \mathrm{l}$ extraction protocol was used for all tissue and water sample extractions. A sample volume of $50 \mu \mathrm{l}$ was used for all oyster tissue extractions. A sample volume of $200 \mu$ was used for all water sample extractions. Nucleic acid preparations were stored at $-20^{\circ} \mathrm{C}$ until qPCR analysis.

\section{Real-time qPCR for detection of OsHV-1}

Samples were analysed in duplicate in a $25 \mu$ total reaction volume as described by Evans et al. (2014). This assay was modified from the fluorescent probe assay described by Martenot et al. (2010). Each reaction contained $12.5 \mu$ l of Quantitect SYBR ${ }^{\circledR}$ green QPCR master mix $(2 \times), 0.5 \mu \mathrm{l}$ of $10 \mu \mathrm{M}$ OsHV1BF forward primer (5' - GTC GCA TCT TTG GAT TTA ACA A-3'), $0.5 \mu \mathrm{l}$ of $10 \mu \mathrm{M}$ OsHV1B4 reverse primer (5'ACT GGG ATC CGA CTG ACA AC-3'), $6.5 \mu$ l of nuclease free water and $5 \mu$ l of sample template DNA.

A valid PCR run was defined as one exhibiting no amplification of negative controls, amplification of both replicates of the positive control with a cycle threshold $(\mathrm{Ct})$ within the range of the standard curve, a standard curve with $\mathrm{r}^{2}>0.95$ and efficiency between 90 and $110 \%$. The fluorescence threshold for each run was calculated using the amplificationbased threshold algorithm (Stratagene) for the standard curves, and was applied to all samples. Samples were defined as positive when one or both replicates exhibited an exponential increase in SYBR fluorescence signal and a $\mathrm{Ct}<40$, with a dissociation curve (Tm) that conformed to that of the positive control. The quantification limit of the assay was 12 viral copies per milligram tissue, and the detection limit 
was 3 viral copies per milligram tissue, according to the calculations and recommendations of Bustin et al. (2009). PCR results below the quantification limit were termed $\mathrm{BLOQ}$, and those with a $\mathrm{Ct}$ value but below the detection limit of the standard curve, BLOD.

Control tissue or water samples that returned a positive result were re-analysed by qPCR by reprocessing either from $-80^{\circ} \mathrm{C}$ stored archival tissue or archival tissue homogenates. The result of the repeat qPCR was accepted as valid if it met the above criteria, and was used in the final analysis.

\section{Statistical analysis}

Descriptive analyses were initially conducted including calculation of summary statistics for quantitative variables and creation of frequency tables for categorical variables. Survival analyses were conducted to compare mortality of oysters between treatment groups using the Kaplan-Meier and Cox's hazard models using Genstat (15th edn, (C) 2000-2015 VSN International Ltd) and SAS (־ 2002-2012 by SAS Institute Inc.), respectively. Oysters that were live sampled were considered to have been censored at the respective observation times. All oysters surviving to the end of the experiment were also censored. The effect of both the number of donor oysters and filter feeding on survival was evaluated. For Expt 2 , separate survival analyses were performed for each period of OsHV-1 exposure. The proportional hazard assumption for the Cox's proportional model was confirmed by evaluating Kaplan-Meier curves and by testing an interaction between time and treatment.

\section{RESULTS}

\section{Expt 1}

The pattern of mortality is shown in Fig. 1. Mortality in OsHV-1 infected donor oysters began on Day 3 in the $\mathrm{HF}^{+}, \mathrm{HF}^{-}$and $\mathrm{LF}^{-}$treatments and on Day 4 in the $\mathrm{LF}^{+}$treatment. All donors were dead by Day 10, except for 1 in $\mathrm{LF}^{+}$. Viral DNA quantities in dead donor oysters ranged from $1.12 \times 10^{3}$ to $5.52 \times 10^{6}$ DNA copies $\mathrm{mg}^{-1}$ tissue, with standard deviations all $<6.5 \times 10^{1}$. Therefore, donors provided a source of OsHV-1 within each tank. The single surviving donor oyster had $6.74 \times 10^{1} \mathrm{DNA}$ copies $\mathrm{mg}^{-1}$ tissue. The number of OsHV-1 infected donors remaining each day is shown in Fig. 1B,D,F,H.
Mortality of the cohabitated oysters in the $\mathrm{HF}^{+}$ treatment began on Day 4 and steeply increased, reaching $100 \%$ by Day 10 . Mortality of the cohabitated oysters in the $\mathrm{HF}^{-}$treatment began on Day 6 at $5 \%$ and reached $72 \%$ by Day 10 . Mortality of the cohabitated oysters in the $\mathrm{LF}^{+}$treatment began on Day 4 at $4 \%$, and increased gradually to Day 8 before plateauing at $49 \%$. Mortality of the cohabitated oysters in the $\mathrm{LF}^{-}$treatment began on Day 6 at $2 \%$ and gradually increased to $22 \%$ by Day 10 (Fig. 1). No mortality occurred in the $\mathrm{NF}^{+}$control. However, 1 oyster died in the $\mathrm{NF}^{-}$control on Day 7.

Survival analysis demonstrated a significant difference between the treatments $(p<0.001)$. Median times to death were 6-7 $\mathrm{d}$ for $\mathrm{HF}^{+}, 8-9 \mathrm{~d}$ for $\mathrm{HF}^{-}$and $7 \mathrm{~d}$ for $\mathrm{LF}^{+}$. Median times to death could not be estimated for the $\mathrm{LF}^{-}$or control groups. Due to intersection of the $\mathrm{HF}^{-}$and $\mathrm{LF}^{+}$survival curves at Day 7 , the proportional hazard assumption was invalid. Inclusion of an interaction term between time and treatment suggested non-proportional hazards ( $p$-value of the interaction term equaled 0.002). Therefore, hazard ratios were calculated separately for Days 1-7 ( $\leq 7 \mathrm{~d})$ and Days 8-10 (>7 d). The hazard of death in the $\mathrm{HF}^{+}$treatment was greater than that in the $\mathrm{HF}^{-}, \mathrm{LF}^{+}$and $\mathrm{LF}^{-}$treatments at $\leq 7 \mathrm{~d}$. The hazard of death in the $\mathrm{LF}^{+}$treatment was greater than that in the $\mathrm{LF}^{-}$treatment at $\leq 7 \mathrm{~d}$. At $>7 \mathrm{~d}$ the confidence limits of the hazard ratios included 1 ; however, there was a trend to higher hazard of death associated with fed oysters exposed to a high dose compared to a low dose of OsHV-1 ( $\mathrm{HF}^{+}$vs. $\mathrm{LF}^{+}$) (Table 3).

The viral load in the cohabitated naïve oysters that died ranged from $1.88 \times 10^{5}$ to $2.00 \times 10^{6}$ DNA copies $\mathrm{mg}^{-1}$ tissue, with standard deviations all $<5$, consistent with levels reported in oysters that have died due to OsHV-1 infection (Oden et al. 2011, Paul-Pont et al. 2015).

In the live cohabitated oysters that were sampled each day, OsHV-1 DNA was first detected in the $\mathrm{HF}^{+}$ treatment on Day 1, but at very low levels, below the limit of quantification (BLOQ) of the qPCR (Fig. 1). The viral load increased to $9.88 \times 10^{4} \pm 3.18 \times 10^{1} \mathrm{DNA}$ copies $\mathrm{mg}^{-1}$ tissue (mean $\pm \mathrm{SD}$ ) by Day 6 . The percentage of oysters with infection increased from 33\% among live sampled oysters on Day 1 to $100 \%$ by Day 6 , then decreased to $33 \%$ on Days 7-8. OsHV-1 DNA was first detected in $\mathrm{HF}^{-}$live sampled oysters on Day 1 at low levels (BLOD). By Day 3 there were $2.06 \times 10^{1} \pm 3.20$ DNA copies $\mathrm{mg}^{-1}$ tissue in live sampled oysters and $2.54 \times 10^{5} \pm 2.15$ by Day 8 . The infection percentage increased from $16 \%$ on Day 1 to $100 \%$ by Day 5 . OsHV1 DNA was first detected in $\mathrm{LF}^{+}$live sampled oysters on 
A $\mathrm{HF}^{+}$
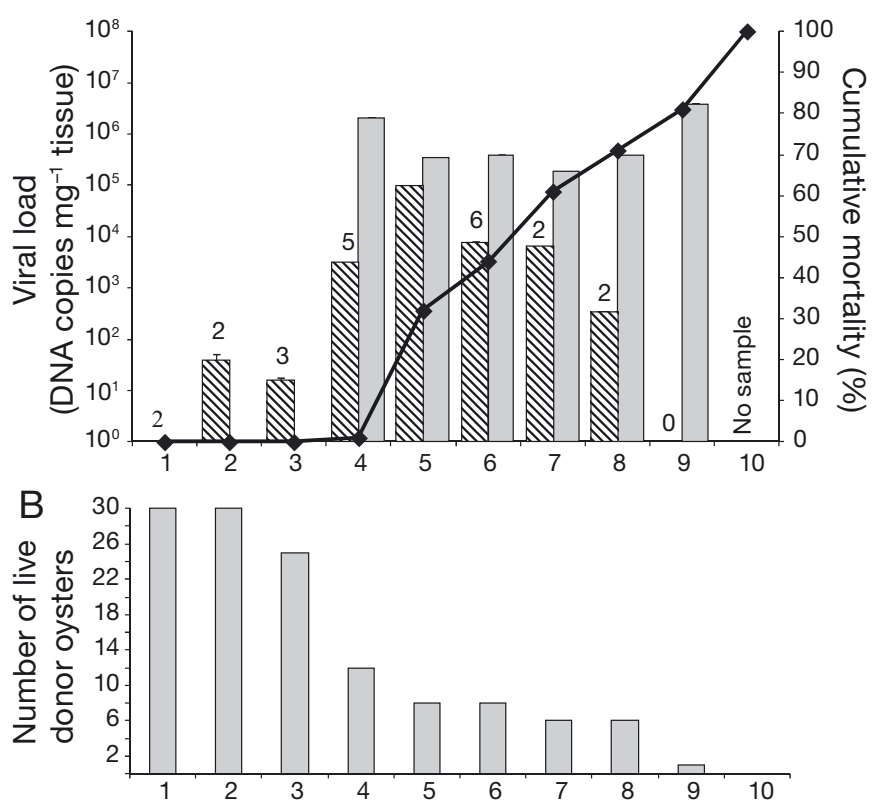

E $\quad \mathrm{LF}^{+}$

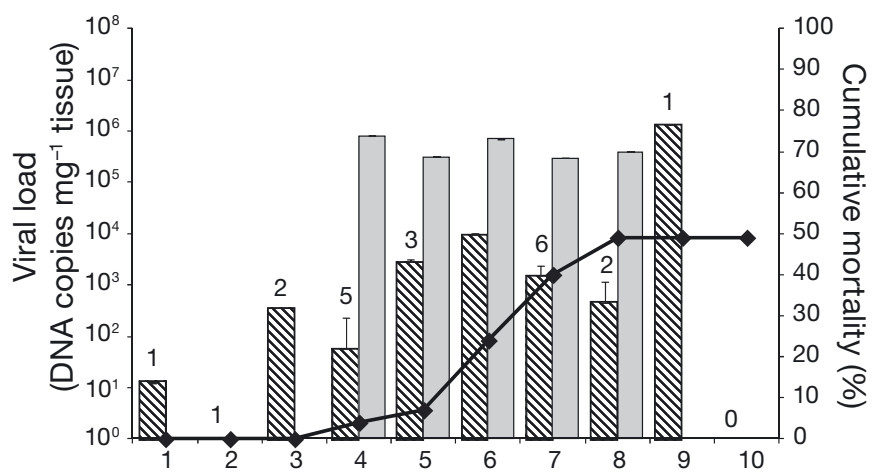

$\mathrm{F}$

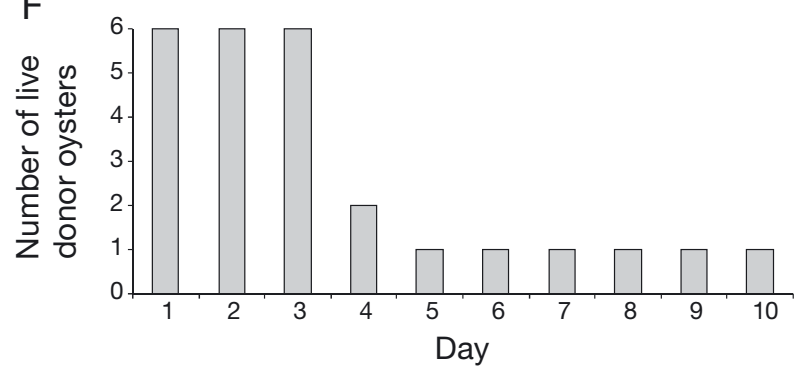

C $\mathrm{HF}^{-}$
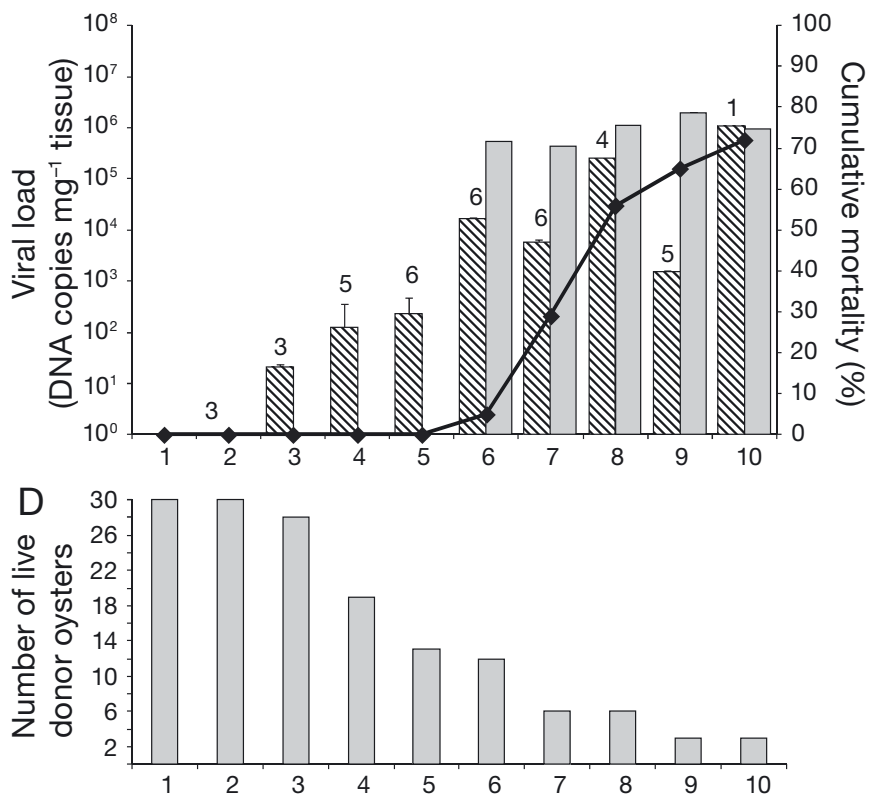

G LF-
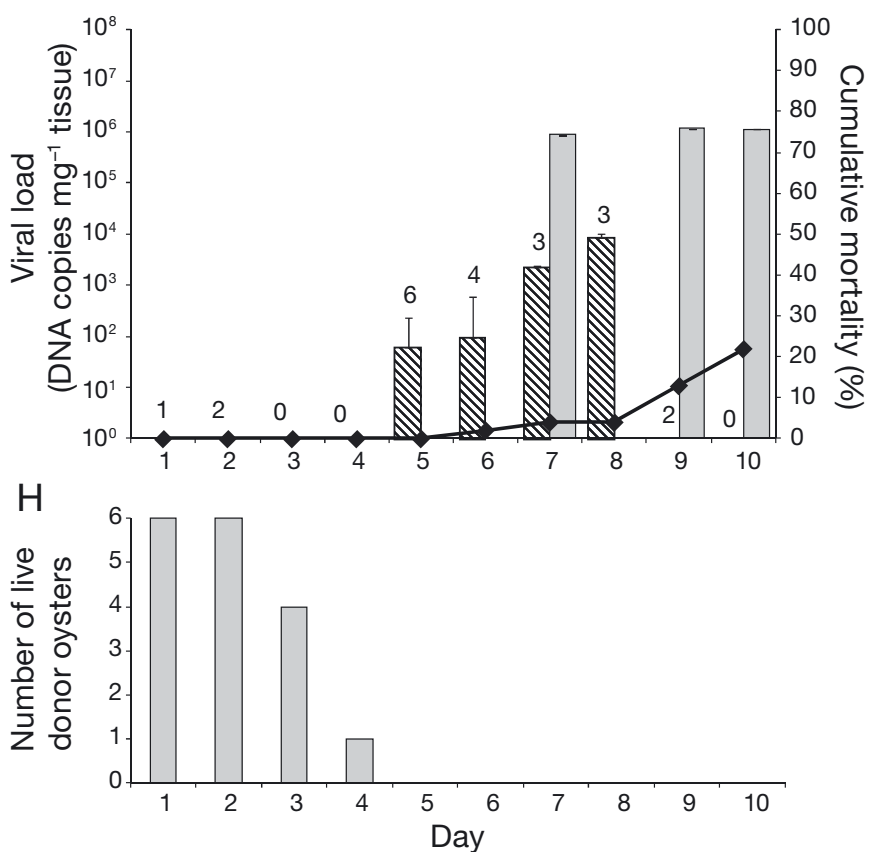

Fig. 1. (A, C,E,G) Cumulative mortality (\%), adjusted for the effects of daily random sampling (line), mean (geometric) viral load (copies $\mathrm{mg}^{-1}$ of tissue, $\pm \mathrm{SD}$ ) of live sampled (striped bar) and dead cohabitated (solid grey bar) oysters (all that died that day) and the number of live infected oysters out of 6 (numbers over bars); and $(\mathrm{B}, \mathrm{D}, \mathrm{F}, \mathrm{H})$ the number of live donor oysters remaining for each of the 4 treatment groups (see Table 1): $(\mathrm{A}, \mathrm{B}) \mathrm{HF}^{+},(\mathrm{C} ; \mathrm{D}) \mathrm{HF}^{-},(\mathrm{E}, \mathrm{F}) \mathrm{LF}^{+},(\mathrm{G}, \mathrm{H}) \mathrm{LF}^{-}$. SD is on the $y$-axis and where it is less than the viral load it is not visible above the bars

Day 1 of the experiment at 13.20 DNA copies $\mathrm{mg}^{-1}$ tissue. Quantities increased to $9.78 \times 10^{3} \pm 4.64 \times 10^{2} \mathrm{DNA}$ copies $\mathrm{mg}^{-1}$ tissue by Day 6 . The infection percentage increased from $16 \%$ on Day 1 to $100 \%$ by Day 6 . The 3 survivors in the $\mathrm{LF}^{+}$treatment all tested negative for OsHV-1 at the end of the experimental period. OsHV-1
DNA was first detected in $\mathrm{LF}^{-}$live sampled oysters on Day 1 (BLOD). OsHV-1 was detected at $6.11 \times 10^{1} \pm 1.69$ $\times 10^{2}$ DNA copies $\mathrm{mg}^{-1}$ tissue on Day 5 and $8.46 \times 10^{3} \pm$ $1.46 \times 10^{3}$ DNA copies $\mathrm{mg}^{-1}$ tissue on Day 8 . The infection percentage was $16 \%$ on Day 1 and $100 \%$ on Day 5 , then decreased to $33 \%$ by Day 9 . OsHV-1 DNA was 
Table 3. Cox's proportional hazards for Expts $1 \& 2$. Period 1: Days 1-8 (OsHV-1 infected donors present Days $1-4 ; \mathrm{n}=6$ donors); Period 2: Days 9-22 (OsHV-1 infected donors present Days 9-12; $\mathrm{n}=18$ donors). Comparisons with $95 \%$ confidence intervals containing the value 1.00 within their range are not significant. See Table $1 \& 2$ for abbreviations

\begin{tabular}{|c|c|c|c|}
\hline \multirow{3}{*}{ Comparisons } & \multicolumn{3}{|c|}{ Hazard ratios } \\
\hline & Point & $95 \%$ confid & ence limits \\
\hline & estimate & Lower & Upper \\
\hline \multicolumn{4}{|l|}{ Expt 1} \\
\hline \multicolumn{4}{|l|}{$\leq 7 \mathrm{~d}$ post-exposure } \\
\hline Treatment $\mathrm{HF}^{+}$vs. $\mathrm{HF}^{-}$ & 3.55 & 1.97 & 6.38 \\
\hline Treatment $\mathrm{HF}^{+}$vs. $\mathrm{LF}^{+}$ & 2.11 & 1.26 & 3.55 \\
\hline Treatment $\mathrm{HF}^{+}$vs. $\mathrm{LF}^{-}$ & 28.92 & 6.97 & 120.92 \\
\hline Treatment $\mathrm{LF}^{+}$vs. $\mathrm{HF}^{-}$ & 1.681 & 0.89 & 3.183 \\
\hline Treatment $\mathrm{LF}^{+}$vs. $\mathrm{LF}^{-}$ & 13.703 & 3.23 & 58.14 \\
\hline $\begin{array}{l}\text { Treatment } \mathrm{HF}^{+} \text {vs. } \\
\text { control } \mathrm{NF}^{+}\end{array}$ & $1.99 \times 10^{7}$ & - & - \\
\hline $\begin{array}{l}\text { Treatment } \mathrm{HF}^{+} \text {vs. } \\
\text { control } \mathrm{NF}^{-}\end{array}$ & 19.46 & 2.67 & 141.87 \\
\hline \multicolumn{4}{|l|}{ > 7 d post-exposure } \\
\hline Treatment $\mathrm{HF}^{+}$vs. $\mathrm{HF}^{-}$ & 0.83 & 0.275 & 2.49 \\
\hline Treatment $\mathrm{HF}^{+}$vs. $\mathrm{LF}^{+}$ & 4.14 & 0.913 & 18.75 \\
\hline Treatment $\mathrm{HF}^{+}$vs. $\mathrm{LF}^{-}$ & 2.61 & 0.802 & 8.53 \\
\hline Treatment $\mathrm{LF}^{+}$vs. $\mathrm{HF}^{-}$ & 0.20 & 0.06 & 0.69 \\
\hline Treatment $\mathrm{LF}^{+}$vs. $\mathrm{LF}^{-}$ & 0.632 & 0.18 & 2.27 \\
\hline $\begin{array}{l}\text { Treatment } \mathrm{HF}^{+} \text {vs. } \\
\text { control } \mathrm{NF}^{+}\end{array}$ & $1.33 \times 10^{7}$ & - & - \\
\hline $\begin{array}{l}\text { Treatment } \mathrm{HF}^{+} \text {vs. } \\
\text { control NF}\end{array}$ & $1.33 \times 10^{7}$ & - & - \\
\hline \multicolumn{4}{|l|}{ Expt 2} \\
\hline \multicolumn{4}{|l|}{ Period 1} \\
\hline Treatment FS vs. SF & 2.05 & 0.20 & 44.01 \\
\hline Treatment FS vs. AS & 2.03 & 0.20 & 43.67 \\
\hline Treatment SF vs. AS & 0.99 & 0.04 & 25.07 \\
\hline \multicolumn{4}{|l|}{ Period 2} \\
\hline Treatment AF vs. FS & 1.57 & 0.76 & 3.24 \\
\hline Treatment AF vs. SF & 1.00 & 0.53 & 1.89 \\
\hline Treatment AF vs. AS & 1.32 & 0.65 & 2.67 \\
\hline Treatment FS vs. SF & 0.64 & 0.31 & 1.31 \\
\hline Treatment FS vs. AS & 0.84 & 0.38 & 1.84 \\
\hline Treatment SF vs. AS & 1.32 & 0.65 & 2.66 \\
\hline
\end{tabular}

detected in $15.8 \%$ of survivors in the $\mathrm{LF}^{-}$treatment, with a mean of $1.45 \times 10^{1} \pm 5.35 \times 10^{1}$ DNA copies $\mathrm{mg}^{-1}$ tissue.

Live sampled $\mathrm{NF}^{-}$controls tested negative for OsHV-1 on Days 1-6 and 8-10, and all survivors in this group tested negative, but OsHV-1 DNA was detected at low levels (BLOQ) in 2 of 2 oysters on Day 7. Viral DNA was detected in 1 dead oyster in the $\mathrm{NF}^{-}$control group, but the viral load was BLOD. No OsHV-1 DNA was detected in the $\mathrm{NF}^{+}$control for Days $1-10$, but 1 out of $10 \mathrm{NF}^{+}$survivors tested positive (BLOD).

\section{Expt 2}

Mortality occurred in infected donors from Day 1-4 (Exposure Period 1) and Day 9-12 (Exposure Period 2), but none of the donors were removed from any tanks until the end of each exposure period. No donors were present between Days 5 and 8. Mean viral loads in OsHV-1 infected donor oysters removed on Day 4 (end Exposure Period 1) and Day 12 (end Exposure Period 2) ranged between $4.62 \times 10^{3}$ and $3.59 \times 10^{5}$ DNA copies $\mathrm{mg}^{-1}$ tissue and $3.69 \times 10^{4}$ and $4.52 \times 10^{5}$ DNA copies $\mathrm{mg}^{-1}$ tissue, respectively, across the 4 treatment groups. Standard deviations were all $<5 \times 10^{1}$. All but 1 of the donors tested positive for OsHV-1 by qPCR. OsHV-1 was not detected in any of the negative control donor oysters at the end of Exposure Period 1 or 2.

The pattern of mortality is shown in Fig. 2. Mortality differed for the 2 exposure periods, with most mortality occurring in Period 2, when naïve oysters were exposed to a larger number of OsHV-1 infected donors (Fig. 2). Mortality in the AF treatment began on Day 13 at $9 \%$, sharply increasing to $33 \%$ by Day 18. Mortality in the FS treatment began on Day 7 at $2 \%$, increasing to $8 \%$ by Day 9 and then to $21 \%$ by Day 16. Mortality in the SF treatment began on Day 8 at $2 \%$, increasing to $35 \%$ by Day 20 . Mortality in the AS treatment began on Day 7 at $2 \%$, steadily increasing to $25 \%$ by Day 20 . No mortality occurred in oysters in any of the control groups (CAF, CFS, CSF, CAS) during the course of the experiment.

There was no significant difference in survival between the treatments in either Period 1 or 2. Median time to death could not be calculated for any treatment. Although the confidence limits for all of the hazard ratios included 1, there was an interesting trend to higher hazard of death associated with food addition (Table 3). In the FS treatment, hazard of death was higher than in the SF and AS treatments for Period 1 (Days 1-8; OsHV-1 infected donors were present Days $1-4 ; \mathrm{n}=6$ ). The hazard of death in the AF treatment was higher than in the FS and AS treatments for Period 2 (Days 9-22; OsHV-1 infected donors were present Days 9-12; $\mathrm{n}=18$ ). The hazard of death in the SF treatment was higher than in the AS treatment for Period 2.

Mean $( \pm \mathrm{SD})$ viral loads (DNA copies $\mathrm{mg}^{-1}$ tissue) in cohabitated live sampled oysters ranged from between $6.19 \times 10^{1} \pm 2.76 \times 10^{0}$ and $1.67 \times 10^{2} \pm 2.26 \times$ $10^{0}$ on Day 4 to $1.49-8.03 \times 10^{3} \pm 3.87 \times 10^{1}$ on Day 17 (Fig. 2). Viral loads in dead cohabitated oysters ranged from $3.50 \times 10^{2}$ to $3.56 \times 10^{7} \mathrm{DNA}$ copies $\mathrm{mg}^{-1}$ tissue in the AF, FS, SF and AS treatments (Fig. 2). The percentages of infection based on detection of OsHV-1 
A
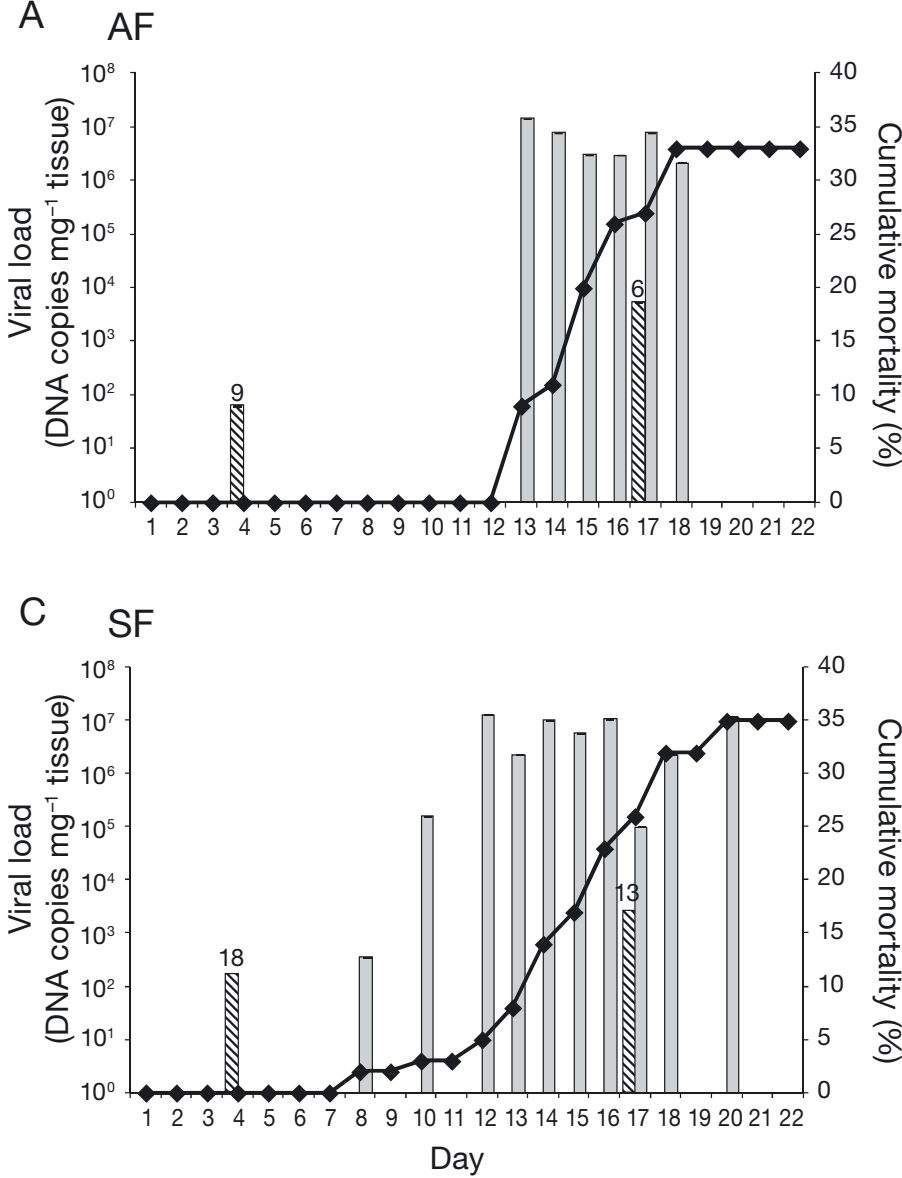

B FS

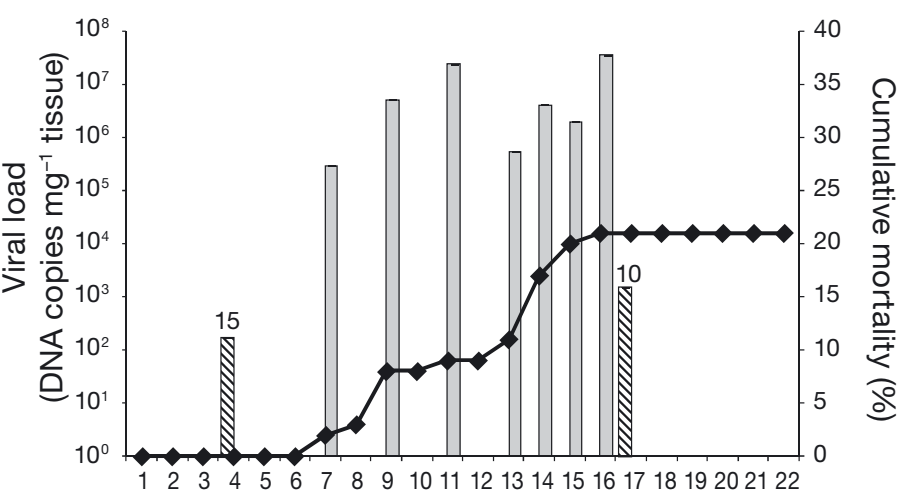

D AS

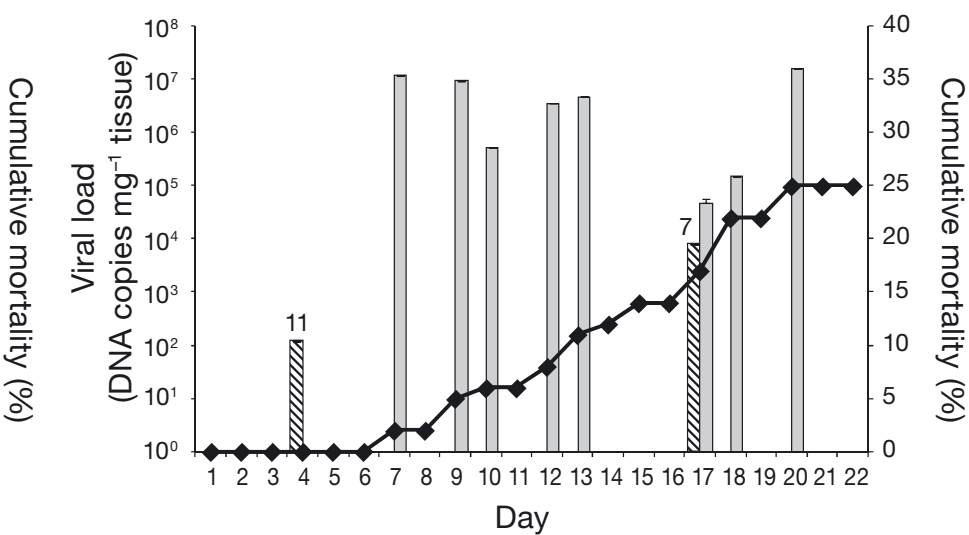

Fig. 2. Cumulative mortality (\%), adjusted for the effects of daily random sampling (line), mean (geometric) viral load (copies $\mathrm{mg}^{-1}$ of tissue, $\pm \mathrm{SD}$ ) (striped bar) and dead cohabited (solid grey bar) oysters (all that died that day), and number of live infected oysters out of 24 (number over bars) for the live sampled oysters, for each of the 4 treatment groups: (A) always fed (AF), (B) fed then starved (FS), (C) starved then fed (SF), and (D) always starved (AS). SD is on the $y$-axis and where it is less than the viral load it is not visible above the bars

DNA in live sampled oysters in the AF, FS, SF and AS groups were $25,62.5,75.0$ and $45.8 \%$, respectively, on Day 4, and 37.5, 41.7, 54.2 and 29.2\%, respectively, on Day 17.

Survivors were present in all treatment groups on Day 22. The percentages of infection in survivors in the AF, FS, SF and AS treatments were 39.1, 27.6, 21.7 and $40.9 \%$, respectively, and corresponding viral loads (mean \pm SD) were $2.11 \times 10^{2} \pm 3.21 \times 10^{0}$, $2.39 \times 10^{3} \pm 6.50 \times 10^{1}, 4.19 \times 10^{1} \pm 1.74 \times 10^{0}$ and $2.56 \times 10^{3} \pm 9.83 \times 10^{1}$ DNA copies $\mathrm{mg}^{-1}$ tissue. All the control oysters survived. The CAF and CFS control groups both tested $21.1 \%$ positive to OsHV-1 at viral loads of $2.48 \times 10^{2} \pm 3.78 \times 10^{0}$ and $9.12 \times 10^{1} \pm$ $1.16 \times 10^{0}$ DNA copies $\mathrm{mg}^{-1}$ tissue, respectively. The CSF control group tested $50 \%$ positive to OsHV-1 with $2.68 \times 10^{2} \pm 3.46 \times 10^{0}$ DNA copies $\mathrm{mg}^{-1}$ tissue. At Day 22 all oysters in the CAS control tested negative to OsHV-1, but OsHV-1 DNA was detected on
Day 17 at $2.38 \times 10^{3}$ DNA copies $\mathrm{mg}^{-1}$ tissue in a single live sampled cohabiting oyster.

\section{Detection of OsHV-1 DNA in water}

OsHV-1 DNA was detected in the tank water of all treatments $\left(\mathrm{HF}^{+}, \mathrm{HF}^{-}, \mathrm{LF}^{+}, \mathrm{LF}^{-}\right)$in Expt 1 from Day 1-9 (Table 4), but was consistently at low levels (BLOQ). OsHV-1 DNA was detected regardless of whether the recirculation, biofiltration and UV treatments were connected or disconnected to treatment tanks. OsHV-1 DNA was detected in the sump water of all treatments across the experimental period; however, it was not detected in the water of the $\mathrm{LF}^{-}$ sump at T2 or T3 for the duration of the experiment. OsHV-1 was detected at quantifiable concentrations only on Day 4 at T2 and T3 (end of the feeding sessions; tanks had had no recirculation, UV, or biofiltra- 
Table 4. Detection of OsHV-1 DNA in water in Expt 1. Treatments are high $(\mathrm{H})$ or low $(\mathrm{L})$ number of donor oysters with $\left(\mathrm{F}^{+}\right)$or without $\left(\mathrm{F}^{-}\right)$feed (see Table 1). T1: Time Point 1 at the start of each day prior to feeding (water exposed to biofiltration and UV by recirculation overnight); T2: Time Point 2 at the end of the morning feeding session (no recirculation, UV, or biofiltration); T3: Time Point 3 at the end of the afternoon feeding session (no recirculation, UV, or biofiltration); T4: Time Point 4 at the end of each day (recirculation, UV and biofiltration); pos: positive; neg: negative; Recirc.: recirculation, biofiltration and UV system connected

\begin{tabular}{|c|c|c|c|c|c|c|c|c|c|c|c|c|}
\hline Source & $\mathrm{T} 1$ & Day & Recirc. & $\mathrm{T} 2$ & Day & Recirc. & T3 & Day & Recirc. & $\mathrm{T} 4$ & Day & Recirc. \\
\hline \multicolumn{13}{|l|}{ Tanks } \\
\hline $\mathrm{HF}^{+}$ & pos & $1-8$ & yes & pos & $1-8$ & no & pos & $1-8$ & no & pos & $1-8$ & yes \\
\hline $\mathrm{HF}^{-}$ & pos & $1-9$ & yes & pos & $1-9$ & no & pos & $1-9$ & no & pos & $1-9$ & yes \\
\hline $\mathrm{LF}^{+}$ & pos & $1-8$ & yes & pos & $1-8$ & no & pos & $1-8$ & no & pos & $1-8$ & yes \\
\hline $\mathrm{LF}^{-}$ & pos & $1-8$ & yes & pos & $1-8$ & no & pos & $1-8$ & no & pos & $1-8$ & yes \\
\hline \multicolumn{13}{|l|}{ Sump } \\
\hline $\mathrm{HF}^{+}$ & pos & $1-8$ & yes & pos & $2,3,5,8$ & yes & pos & 2,6 & yes & pos & $1-8$ & yes \\
\hline $\mathrm{HF}^{-}$ & pos & $1-9$ & yes & pos & $2,3,5,8$ & yes & pos & 2,9 & yes & pos & $1-9$ & yes \\
\hline $\mathrm{LF}^{+}$ & pos & $1-8$ & yes & pos & $1,6,8,9$ & yes & pos & $1,6,8,9$ & yes & pos & $1-8$ & yes \\
\hline $\mathrm{LF}^{-}$ & pos & $2,5,7,8$ & yes & neg & $1-10$ & yes & neg & $1-10$ & yes & pos & $2,5,7,8$ & yes \\
\hline
\end{tabular}

Table 5. Detection of OsHV-1 DNA in water in Expt 2. Treatments are oysters always fed (AS), fed then starved (FS), starved then fed (SF) and always starved (AS) (see Table 2). Other abbreviations as in Table 4

\begin{tabular}{|lcccccc|}
\hline Source & T1 & Day & Recirc. & T3 & Day & Recirc. \\
\hline Tanks & & & & & & \\
AF & pos & $6,10-14$ & yes & pos & $4,9-14$ & no \\
FS & pos & $3,4,7,12,14$ & yes & pos & $2-6,8,12-14$ & no \\
SF & pos & $11,13,14$ & yes & pos & $2,7,9-14$ & no \\
AS & pos & $4,5,13,14$ & yes & pos & $2,3,7,9,13$ & no \\
& & & & & & \\
Sump & & & & & & \\
AF & pos & 10 & yes & pos & 4 & yes \\
FS & pos & 4 & yes & pos & 13 & yes \\
SF & pos & 14 & yes & pos & 2,7 & yes \\
AS & pos & 4 & yes & pos & 3 & yes \\
& & & & & & \\
\hline
\end{tabular}

tion for $2 \mathrm{~h}$ ) in the $\mathrm{HF}^{+}$treatment at $1.89 \times 10^{1}$ and $1.45 \times 10^{1}$ DNA copies $\mu \mathrm{l}^{-1}$, respectively; and in the $\mathrm{HF}^{-}$treatment on Day 6 at T2 at $1.17 \times 10^{1} \mathrm{DNA}$ copies $\mu \mathrm{l}^{-1}$. OsHV-1 was not detected in the tank water of either the $\mathrm{NF}^{+}$or $\mathrm{NF}^{-}$controls for the duration of the experiment.

In Expt 2 OsHV-1 DNA was detected in the tank water of all treatments (AF, FS, SF, AS) from Day 1-14 (Table 5), but was consistently at low levels (BLOQ). OsHV-1 DNA was detected regardless of whether the recirculation, biofiltration and UV treatments were connected or disconnected to treatment tanks. OsHV-1 DNA was detected intermittently in the sump water of all treatments from Day 2-14. OsHV-1 was detected at quantifiable concentrations at T3 (end of the afternoon feeding session; no recirculation, UV, or biofiltration for $2 \mathrm{~h}$ ) on Day 11 at $2.69 \times 10^{1} \pm 3.02 \times 10^{0}$ DNA copies $\mu l^{-1}$ (mean \pm SD).

\section{DISCUSSION}

This is the first study to investigate the effects of food addition on OsHV-1 transmission and clinical disease in Crassostrea gigas. The results of Expt 1 indicated that food presence was an important risk factor for OsHV-1 disease expression. Fed C. gigas had a higher risk of death than starved oysters (3.55-13.70 times). While not the first study to examine the effects of OsHV-1 dose rate on OsHV-1 transmission and expression of clinical disease (Paul-Pont et al. 2015, Petton et al. 2015), this study is unique in its application of experimentally infected donor oysters as a proxy for dose of OsHV-1, whereby the number of infected donors per tank was made 'high' or 'low' in order to change the dose of OsHV-1 to which naïve cohabitating oysters were exposed. Cohabitation of C. gigas with conspecifics that have been experimentally infected with OsHV-1 by intramuscular injection was demonstrated previously to be an effective means for OsHV-1 transmission and reproduction of clinical disease in the laboratory (Schikorski et al. 2011a).

The results of Expt 1 showed a significant difference in mortality between the treatments due to presence of food ( $p<0.001)$. Visual inspection of the turbidity of the water during food addition, inspection of the gut size/content of oysters when they were dissected and observation of faecal matter deposition at the bottom of the tanks was used to confirm that oysters in the food treatments were in fact feeding on the algal diet added to tanks (Iglesias et al. 1998, Lefebvre et al. 2000). Fed oysters not only had a greater level of mortality $(72-100 \%)$, but also a shorter incubation period (median time to death- $\mathrm{HF}^{+}: 6-7 \mathrm{~d}, \mathrm{LF}^{+}: 7 \mathrm{~d}$ ) than starved oysters $\left(22-49 \%, \mathrm{HF}^{-}\right.$: 8-9 d), regardless of 
the number of OsHV-1 infected donor oysters that were present (high or low dose). It has been suggested previously that seawater nutrient content, oyster energy reserves and starvation may be important in the expression of OsHV-1 clinical disease (Pernet et al. 2014, Tamayo et al. 2014, Moreau et al. 2015). Starvation of C. gigas for $4 \mathrm{wk}$ prior to OsHV-1 infection induced autophagy, an innate immune response, and when autophagy was inhibited by $\mathrm{NH}_{4} \mathrm{Cl}$, there was lower survival (Moreau et al. 2015). It has also been suggested that oysters with limited, or no, access to food mobilise their energy stores to respond to OsHV1 infection; the protein, carbohydrate and triglyceride content of oysters declined during infection at $20.6^{\circ} \mathrm{C}$ in comparison with non-exposed $C$. gigas (Pernet et al. 2014, Tamayo et al. 2014). The lower cumulative mortality observed in non-fed oyster treatments in Expt 1 is consistent with the general findings of these earlier studies, in that lack of available feed in seawater was protective against OsHV-1 clinical disease expression.

Planktonic organisms, including zooplankton, microzooplankton, phytoplankton, microphytoplankton, microalgae, flagellates, dinoflagellates, diatoms, ciliates, copepods, bivalve larvae and rotifers, are known to contribute to the typical, yet highly variable, diet of C. gigas in the natural environment (Shumway et al. 1985, Riisgard 1988, Ponis et al. 2003). Studies of natural disease events have suggested that an aquatic mechanical vector or particle may be associated with OsHV-1 transmission, with the spatial patterns of oyster mortalities noted to appear similar to the spatial distributions of planktonic aggregations and communities (Paul et al. 1993, Kingsford \& Suthers 1994, 1996, Ryan et al. 2008, Rissik et al. 2009, Benoit-Bird \& McManus 2012) and it was hypothesised that the virus was attached to such particles (Paul-Pont et al. 2013a). Evans et al. (2014) suggested that OsHV-1 may be present in seawater in a range of forms, including virus adsorbed to particles because centrifugation of seawater samples at $1000 \times g$ for $20 \mathrm{~min}$ with testing of the resultant pellet improved the rate of OsHV-1 detection by real-time qPCR 2-fold ( $\mathrm{p}<$ 0.0001), in comparison with unprocessed seawater samples. As centrifugal forces as low as $1000 \times g$ applied for $20 \mathrm{~min}$ are capable of pelleting particles the same size as plant or animal cells (or larger), and not particulates as small as free virus (Lawrence \& Steward 2010), it was strongly suggested that at least some OsHV-1 virions may be attached to or associated with particles within natural seawater samples. Whittington et al. (2015b) demonstrated that treatment of incoming OsHV-1 infected seawater, by either aging or filtration to $5 \mu \mathrm{m}$, can prevent OsHV1 related mortalities in C. gigas spat. OsHV-1 was however sometimes detected at very low levels in aged and filtered seawater treatment spat. Thus, it was unclear whether it was removal of the particle to which OsHV-1 may have been adsorbed, or removal of the oyster feed, or a combination of the 2 that was important to limit OsHV-1 transmission and expression of the disease. It is unknown whether OsHV-1 became adsorbed to the microalgal species in the diet concentrate that was fed during the current trial, or whether the action of oyster feeding simply created a means of increased viral entry. Commercially cultured $C$. gigas have been shown to have a filtration rate of $0.73 \mathrm{l} \mathrm{g}^{-1} \mathrm{~h}^{-1}$ (shucked dry weight) for longline culture, compared to values of 2.5-12 $\mathrm{l} \mathrm{g}^{-1} \mathrm{~h}^{-1}$ reported from laboratory studies (Wheat \& Ruesink 2013). However, while it is apparent that the presence of food is an important risk factor for OsHV-1 mortality, it remains unclear how filter feeding, and variations in filtration rate, relates to and impacts viral transmission. Further investigation of the adsorptive capacity, and stability, of OsHV-1 in relation to plankton, such as the marine algal species used in the current trial, and the filtration and ingestion of such algae by oysters is required to answer these questions. A related virus called AVNV was reported to adsorb to several species of microalgae to form an AVNVinfected algal complex, which when fed to Zhikong scallops caused significant mortalities in comparison to scallops fed non-infected microalgae (Wang et al. 2010, Zhang et al. 2010).

In Expt 2 mortality rates in the AF, FS, SF and AS treatments were low $(<35 \%)$ and were not significantly different from one another, and the trend to a higher hazard of death associated with feeding during periods of OsHV-1 exposure must be interpreted with caution. However, as in Expt 1, the presence of food during OsHV-1 exposure may have influenced OsHV-1 related mortality. The number of OsHV-1 infected donors was also important, as mortality following the first exposure period ( $\mathrm{n}=6$ infected donor oysters), that is the first $8 \mathrm{~d}$ of the trial comprising $4 \mathrm{~d}$ of exposure and the following $4 \mathrm{~d}$ during which there were no donor oysters present was negligible compared to that following the second exposure period ( $\mathrm{n}=18$ infected donor oysters) (Fig. 2). There was a strong effect of OsHV-1 dosage in the intramuscular injection model described by Paul-Pont et al. (2015); doses $<5.1 \times 10^{2}$ DNA copies $\mathrm{mg}^{-1}$ were not lethal. Petton et al. (2015) also used a cohabitation model, but unlike that in the present study, it involved donors exposed to OsHV-1 in the natural environment 
rather than donors injected with a known quantity of partially purified virus. The biomass of donors varied between treatments and, while tests for OsHV-1 were not performed on all of the donors, OsHV-1 DNA was quantified in some, so increasing the biomass of donors would have corresponded to an increasing dose, and this was correlated with mortality.

In Expt 2 it was thought that successive OsHV-1 exposures, of differing intensities, may mimic what is observed in the field in Australia, where oysters are exposed several times over the course of a season (Whittington et al. 2015a). The results of an earlier study led to the suggestion that $C$. gigas may be capable of developing an antiviral immune response as a result of prior immune stimulus (Green \& Montagnani 2013). Such an immune response may possibly account for the overall low mortality observed across treatments in Expt 2, but immune responses were not evaluated. However, OsHV-1 was detected in live sampled oysters from all treatment groups on Day 4 at the conclusion of the Exposure Period 1, confirming exposure.

The higher overall cumulative mortality in C. gigas juveniles in Expt 1 compared with Expt 2 (Figs. 1 \& 2) was probably not related to husbandry of oysters as the aquarium systems, water quality parameters and protocols used in the 2 trials were consistent. However, Expts 1 \& 2 were conducted 18 mo apart, and the batches of oysters were not standardised. It is plausible that the batches of oysters and their genetics were sufficiently different to explain the variable clinical outcomes (Dégremont 2013, Dégremont et al. 2015). In addition, the exposure periods and doses of OsHV-1 were different; in the first trial there was continuous exposure to OsHV-1, while in the second trial, which was intended to simulate the effects of successive OsHV-1 exposures, there was a $4 \mathrm{~d}$ exposure at a relatively low dose, followed by a $4 \mathrm{~d}$ gap when no donors were present, then a $4 \mathrm{~d}$ exposure to a higher dose.

Other authors have suggested that water acts as a medium in the horizontal transmission of OsHV-1 (Schikorski et al. 2011a). OsHV-1 DNA was detected in water samples across the sampling periods in both Expts $1 \& 2$, but at very low levels (below the limits of quantification or theoretical detection for the qPCR assay) regardless of whether the recirculation, biofiltration and UV systems were connected to the experimental tanks. Higher viral quantities were detected in tank water in prior studies: $10^{1}-10^{3}$ DNA copies $\mathrm{\mu l}^{-1}$ seawater (Schikorski et al. 2011a) and $2.5 \times 10^{2}$ to $1.8 \times 10^{6}$ DNA copies $\mathrm{ml}^{-1}$ (Paul-Pont et al. 2015). However, these low viral DNA quantities are consis- tent with those seen in natural seawater samples collected during outbreaks of mortality in cultured $C$. gigas (Evans et al. 2014). The large water volumes of the recirculation systems (300 l), as well as the presence of the biofiltration and UV treatments, may explain the low viral quantities detected compared to other studies, for example Schikorski et al. (2011a) who used static tanks of 25 l. OsHV-1 DNA was only detected at quantifiable concentrations at times when feeding was being performed and the recirculation, biofiltration and UV were disconnected from the experiment tanks. In all studies, it is possible that OsHV-1 detected by qPCR was in the form of free virus, virus associated with particulates such as feed or oyster cells or faeces, or free viral DNA (Evans et al. 2014). Further investigation is required to ascertain the form of the virus being detected, as well as the mechanism of infection.

\section{CONCLUSIONS}

This is the first study to investigate the effect of food on OsHV-1 transmission and clinical disease. Cohabitation of OsHV-1 infected donor oysters with naïve Crassostrea gigas $<1$ yr of age was a successful model for OsHV-1 disease expression as has been shown previously. However, this was influenced by the number of donor oysters per tank, which was used as a proxy for infectious biomass (i.e. dose of OsHV-1). In the first experiment, at both high and low doses, food presence increased the hazard of death due to waterborne OsHV-1 exposure - by 3.55 to 13.70 times. Incubation period (median time to death) was shorter (6-7 d) in fed oysters compared to non-fed oysters (>8 d). Fed oysters cohabitated with 6 OsHV-1 infected donor oysters per tank had a 28.92-fold greater risk of death than non-fed oysters cohabitated with 2 donor oysters per tank in the first week post-exposure. Mortality rate was lower in a second experiment, possibly due to use of different oyster batches and doses, highlighting the need to standardise factors for such experiments. OsHV-1 DNA was detected in the water in both experiments, but concentrations of the virus in water were lower than those reported in previous studies, probably due to much higher tank volume and use of recirculation, UV and filtration systems. Results are consistent with the hypothesis that OsHV1 may be attached to particles which are important for transmission of the virus. However, OsHV-1 adsorption to algal food particles and whether ingestion of infected food is the mechanism by which oysters become infected is yet to be confirmed. 
Acknowledgements. This work was funded by the Australian Government through the Fisheries Research and Development Corporation and by the University of Sydney. Slavicka Patten, Craig Kristo and Stuart Glover are thanked for their technical assistance in preparing for the trials. Oysters were kindly provided by Shellfish Culture Tasmania. Leon and Angela Riepsamen and Bruce Alford provided expert care for experimental oysters in the Shoalhaven and Hawkesbury Rivers, respectively.

\section{LITERATURE CITED}

Arzul I, Renault T, Thebault A, Gerard A (2002) Detection of oyster herpesvirus DNA and proteins in asymptomatic Crassostrea gigas adults. Virus Res 84:151-160

Bai C, Wang C, Xia J, Sun H, Zhang S, Huang J (2015) Emerging and endemic types of Ostreid herpesvirus 1 were detected in bivalves in China. J Invertebr Pathol 124:98-106

Benoit-Bird KJ, McManus MA (2012) Bottom-up regulation of a pelagic community through spatial aggregations. Biol Lett 8:813-816

Bustin SA, Benes V, Garson JA, Hellemans J and others (2009) The MIQE guidelines: minimum information for publication of quantitative real-time PCR experiments. Clin Chem 55:611-622

> Cotter E, Malham SK, O'Keeffe S, Lynch SA and others (2010) Summer mortality of the Pacific oyster, Crassostrea gigas, in the Irish sea: the influence of growth, biochemistry and gametogenesis. Aquaculture 303:8-21

> Dégremont L (2013) Size and genotype affect resistance to mortality caused by OsHV-1 in Crassostrea gigas. Aquaculture 416/417:129-134

> Dégremont L, Boudry P, Ropert M, Samain JF, Bedier E, Soletchnik P (2010) Effects of age and environment on survival of summer mortality by two selected groups of the Pacific oyster Crassostrea gigas. Aquaculture 299:44-50

Dégremont L, Garcia C, Allen JSK (2015) Genetic improvement for disease resistance in oysters: a review. J Invertebr Pathol 131:226-241

Evans O, Paul-Pont I, Hick P, Whittington R (2014) A simple centrifugation method for improving the detection of Ostreid herpesvirus-1 (OsHV-1) in natural seawater samples with an assessment of the potential for particulate attachment. J Virol Methods 210:59-66

FAO (Food and Agriculture Organization of the United Nations) (2004) Hatchery culture of bivalves - a practical manual. In: Lovatelli A (ed) FAO Fisheries Technical Paper 471. FAO, Rome, p 203

Farley CA, Foster WS, Banfield WG, Kasnic G (1972) Oyster herpes-type virus. Science 178:759-760

> Garcia C, Thebault A, Dégremont L, Arzul I and others (2011) Ostreid herpesvirus 1 detection and relationship with Crassostrea gigas spat mortality in France between 1998 and 2006. Vet Res 42:73

Green TJ, Montagnani C (2013) Poly I:C induces a protective antiviral immune response in the Pacific oyster (Crassostrea gigas) against subsequent challenge with Ostreid herpesvirus (OsHV-1 $\mu v a r)$. Fish Shellfish Immunol 35:382-388

Hwang JY, Park JJ, Yu HJ, Hur YB, Arzul I, Couraleau Y, Park MA (2013) Ostreid herpesvirus 1 infection in farmed Pacific oyster larvae Crassostrea gigas (Thunberg) in Korea. J Fish Dis 36:969-972
ICTV (International Committee on Taxonomy of Viruses) (2013) International committee on taxonomy of viruses: virus taxonomy 2013 release. ICTV, Edinburgh

Iglesias JIP, Urrutia MB, Navarro E, Ibarrola I (1998) Measuring feeding and absorption in suspension-feeding bivalves: an appraisal of the biodeposition method. J Exp Mar Biol Ecol 219:71-86

Jenkins C, Hick P, Gabor M, Spiers Z and others (2013) Identification and characterisation of an Ostreid herpesvirus-1 microvariant (OsHV-1 $\mu$-var) in Crassostrea gigas (Pacific oysters) in Australia. Dis Aquat Org 105: 109-126

Keeling SE, Brosnahan CL, Williams R, Gias E and others (2014) New Zealand juvenile oyster mortality associated with Ostreid herpesvirus 1 - an opportunistic longitudinal study. Dis Aquat Org 109:231-239

> Kingsford MJ, Suthers IM (1994) Dynamic estuarine plumes and fronts - importance to small fish and plankton in coastal waters of NSW, Australia. Cont Shelf Res 14: 655-672

Kingsford MJ, Suthers IM (1996) The influence of tidal phase on patterns of ichthyoplankton abundance in the vicinity of an estuarine front, Botany Bay, Australia. Estuar Coast Shelf Sci 43:33-54

Lawrence JE, Steward GF (2010) Purification of viruses by centrifugation. In: Wilhelm SW, Weinbauer MG, Suttle CA (eds) Manual of aquatic viral ecology. American Society of Limnology and Oceanography, p 166-181

Lefebvre S, Barille L, Clerc M (2000) Pacific oyster (Crassostrea gigas) feeding responses to a fish-farm effluent. Aquaculture 187:185-198

Martenot C (2013) Variants of the Ostreid herpesvirus-1 (OsHV-1) in the Crassostrea gigas oyster. Virologie 17: 81-87

Martenot C, Oden E, Travaille E, Malas JP, Houssin M (2010) Comparison of two real-time PCR methods for detection of Ostreid herpesvirus 1 in the Pacific oyster Crassostrea gigas. J Virol Methods 170:86-89

Martenot C, Oden E, Travaille E, Malas JP, Houssin M (2011) Detection of different variants of Ostreid herpesvirus 1 in the Pacific oyster, Crassostrea gigas between 2008 and 2010. Virus Res 160:25-31

> Moreau P, Moreau K, Segarra A, Tourbiez D, Travers MA, Rubinsztein DC, Renault T (2015) Autophagy plays an important role in protecting Pacific oysters from OsHV-1 and Vibrio aestuarianus infections. Autophagy 11: $516-526$

- Mori K (1979) Effects of artificial eutrophication on the metabolism of the Japanese oyster Crassostrea gigas. Mar Biol 53:361-369

Nicholas J, Comps M, Cochennec N (1992) Herpes-like virus infecting Pacific oyster larvae, Crassostrea gigas. Bull Eur Assoc Fish Pathol 12:11-13

Normand J, Blin JL, Jouaux A (2014) Rearing practices identified as risk factors for ostreid herpesvirus 1 (OsHV-1) infection in Pacific oyster Crassostrea gigas spat. Dis Aquat Org 110:201-211

Oden E, Martenot C, Berthaux M, Travaille E, Malas JP, Houssin M (2011) Quantification of Ostreid herpesvirus 1 (OsHV-1) in Crassostrea gigas by real-time PCR: determination of a viral load threshold to prevent summer mortalities. Aquaculture 317:27-31

Paul JH, Rose JB, Jiang SC, Kellogg CA, Dickson L (1993) Distribution of viral abundance in the reef environment of Key Largo, Florida. Appl Environ Microbiol 59:718-724 
Paul-Pont I, Dhand NK, Whittington RJ (2013a) Spatial distribution of mortality in Pacific oysters Crassostrea gigas: reflection on mechanisms of OsHV-1 transmission. Dis Aquat Org 105:127-138

Paul-Pont I, Dhand NK, Whittington RJ (2013b) Influence of husbandry practices on OsHV-1 associated mortality of Pacific oysters Crassostrea gigas. Aquaculture 412/413: 202-214

Paul-Pont I, Evans O, Dhand N, Rubio A, Coad P, Whittington R (2014) Descriptive epidemiology of mass mortality due to Ostreid herpesvirus-1 (OsHV-1) in commercially farmed Pacific oysters (Crassostrea gigas) in the Hawkesbury River estuary, Australia. Aquaculture 422-423:146-159

Paul-Pont I, Evans O, Dhand NK, Whittington RJ (2015) Experimental infections of Pacific oyster Crassostrea gigas using the Australian ostreid herpesvirus-1 (OsHV1) $\mu$ Var strain. Dis Aquat Org 113:137-147

> Peeler EJ, Reese RA, Cheslett DL, Geoghegan F, Power A, Thrush MA (2012) Investigation of mortality in Pacific oysters associated with Ostreid herpesvirus-1 $\mu$ var in the Republic of Ireland in 2009. Prev Vet Med 105:136-143

Pepin JF, Riou A, Renault T (2008) Rapid and sensitive detection of Ostreid herpesvirus 1 in oyster samples by real-time PCR. J Virol Methods 149:269-276

> Pernet F, Barret J, Le Gall P, Corporeau C and others (2012) Mass mortalities of Pacific oysters Crassostrea gigas reflect infectious diseases and vary with farming practices in the Mediterranean Thau lagoon, France. Aquacult Environ Interact 2:215-237

Pernet F, Lagarde F, Jeannee N, Daigle G and others (2014) Spatial and temporal dynamics of mass mortalities in oysters is influenced by energetic reserves and food quality. PLoS ONE 9:e88469

Petton B, Pernet F, Robert R, Boudry P (2013) Temperature influence on pathogen transmission and subsequent mortalities in juvenile Pacific oysters Crassostrea gigas. Aquacult Environ Interact 3:257-273

> Petton B, Boudry P, Alunno-Bruscia M, Pernet F (2015) Factors influencing disease-induced mortality of Pacific oysters Crassostrea gigas. Aquacult Environ Interact 6: 205-222

> Ponis E, Robert R, Parisi G (2003) Nutritional value of fresh and concentrated algal diets for larval and juvenile Pacific oysters (Crassostrea gigas). Aquaculture 221:491-505

Renault T, Arzul I (2001) Herpes-like virus infections in hatchery-reared bivalve larvae in Europe: specific viral DNA detection by PCR. J Fish Dis 24:161-167

Renault T, Le Deuff RM, Cochennec N, Maffart P (1994) Herpesviruses associated with mortalities among Pacific oyster, Crassostrea gigas, in France-comparative study. Rev Med Vet 145:735-742

Renault T, Bouquet AL, Maurice JT, Lupo C, Blachier P (2014) Ostreid herpesvirus-1 infection among Pacific oyster (Crassostrea gigas) spat: relevance of water temperature to virus replication and circulation prior to the onset of mortality. Appl Environ Microbiol 80:5419-5426

Riisgard HU (1988) Efficiency of particle retention and filtration rate in 6 species of Northeast American bivalves. Mar Ecol Prog Ser 45:217-223

Rissik D, Shon EH, Newell B, Baird ME, Suthers IM (2009) Plankton dynamics due to rainfall, eutrophication, dilution, grazing and assimilation in an urbanized coastal lagoon. Estuar Coast Shelf Sci 84:99-107
Roque A, Carrasco N, Andree KB, Lacuesta Band others (2012) First report of OsHV-1 microvar in Pacific oyster (Crassostrea gigas) cultured in Spain. Aquaculture 324/325:303-306

> Ryan NJ, Mitrovic SM, Bowling LC (2008) Temporal and spatial variability in the phytoplankton community of Myall lakes, Australia, and influences of salinity. Hydrobiologia 608:69-86

Sauvage C, Pepin JF, Lapegue S, Boudry P, Renault T (2009) Ostreid herpes virus 1 infection in families of the Pacific oyster, Crassostrea gigas, during a summer mortality outbreak: differences in viral DNA detection and quantification using real-time PCR. Virus Res 142:181-187

Schikorski D, Faury N, Pepin JF, Saulnier D, Tourbiez D, Renault T (2011a) Experimental Ostreid herpesvirus 1 infection of the Pacific oyster Crassostrea gigas: kinetics of virus DNA detection by q-PCR in seawater and in oyster samples. Virus Res 155:28-34

Schikorski D, Renault T, Saulnier D, Faury N, Moreau P, Pepin JF (2011b) Experimental infection of Pacific oyster Crassostrea gigas spat by Ostreid herpesvirus 1: demonstration of oyster spat susceptibility. Vet Res 42:27

> Segarra A, Pepin JF, Arzul I, Morga B, Faury N, Renault T (2010) Detection and description of a particular Ostreid herpesvirus 1 genotype associated with massive mortality outbreaks of Pacific oysters, Crassostrea gigas, in France in 2008. Virus Res 153:92-99

> Shimahara Y, Kurita J, Kiryu I, Nishioka T and others (2012) Surveillance of type 1 Ostreid herpesvirus (OsHV-1) variants in Japan. Fish Pathol 47:129-136

Shumway SE, Cucci TL, Newell RC, Yentsch CM (1985) Particle selection, ingestion, and absorption in filter-feeding bivalves. J Exp Mar Biol Ecol 91:77-92

- Tamayo D, Corporeau C, Petton B, Quere C, Pernet F (2014) Physiological changes in Pacific oyster Crassostrea gigas exposed to the herpesvirus OsHV-1 $\mu$ var. Aquaculture 432:304-310

> Vigneron V, Solliec G, Montanié H, Renault T (2004) Detection of Ostreid Herpesvirus 1 (OsHV-1) DNA in seawater by PCR: influence of water parameters in bioassays. Dis Aquat Org 62:35-44

Wang N, Li Y, Cai Y, Ren W, Wang C (2010) Detection of acute viral necrosis virus (AVNV) in plankton using FQ-PCR during a molecular epidemiology survey. J Fish China 34:1566-1571

Wheat E, Ruesink JL (2013) Commercially-cultured oysters (Crassostrea gigas) exert top-down control on intertidal pelagic resources in Willapa Bay, Washington, USA. J Sea Res 81:33-39

> Whittington RJ, Dhand NK, Evans O, Paul-Pont I (2015a) Further observations on the influence of husbandry practices on OsHV-1 $\mu$ var mortality in Pacific oysters Crassostrea gigas: age, cultivation structures and growing height. Aquaculture 438:82-97

- Whittington RJ, Hick P, Evans O, Rubio A, Alford B, Dhand N, Paul-Pont I (2015b) Protection of Pacific oyster (Crassostrea gigas) spat from mortality due to Ostreid herpesvirus 1 (OsHV-1 uvar) using simple treatments of incoming seawater in land-based upwellers. Aquaculture 437:10-20

> Zhang J, Li Y, Ren W, Cai Y (2010) Studies on phytoplanktons carrying and spreading AVNV. J Fish China 34: 1254-1259

Submitted: August 25, 2015; Accepted: October 27, 2015 Proofs received from author(s): December 1, 2015 